\title{
Floristic survey of The Nature Conservancy's Pennington Creek preserve in Johnston County, Oklahoma 1997
}

\author{
Kimberly A. Shannon* \\ Graduate College \\ Oklahoma State University
}

This study was conducted as one part of an overall biological assessment of The Nature Conservancy's Pennington Creek site. A 9.6 hectare area was surveyed during the 1995 and 1996 growing seasons for plants in fertile condition. They were collected, identified and voucher specimens were deposited in the OSU Herbarium (OKLA). Physiographic and ecological aspects of the site were described using Geographic Information System (GIS) techniques. Two hundred-three species representing 157 genera and 63 families were collected. Four plant communities are present: forest, grassland, granitic outcrop, and riparian. Characteristic taxa of the forest community include Quercus stellata, $Q$. marilandica, Carya texana, C. cordiformis, Symphoricarpos orbiculatus, and Elymus canadensis. Tridens flavus, Setaria lutescens, Sorghastrum nutans and Gaillardia pulchella are dominants found in the grasslands. The granitic outcrop areas provide habitat for: Sedum pulchellum, S. nuttallianum, Krigia virginica, Chaetopappa asteroides, and Polypodium polypodioides. Characteristic species of the riparian community include Carex spp., Cyperus spp., Chasmanthium latifolium, Platanus occidentalis, and Alnus maritima.

* Author's current address: Oklahoma Biological Survey, University of Oklahoma, Norman, OK 73019-5112

\section{INTRODUCTION}

Floristic studies have long been an important means of understanding the plants, vegetation, and ecosystems that surround us. Traditionally floristic surveys have covered relatively large areas, but much can be learned from the survey of small ones as well. One such area is a preserve of The Nature Conservancy located in Johnston County in southcentral Oklahoma. Situated on an outcrop of Precambrian granite, it is a 3.2 hectare site that has a number of plant communities; deciduous forest, grasslands, riparian, and granitic outcrop, each with a characteristic assemblage of species. The significance of this site is that exposed
Precambrian granite is relatively infrequent in Oklahoma, composing less than 1 percent of the rock outcrop cover of the state and restricted primarily to a small portion in the south-central part (1). These Precambrian outcrop areas typically have an interesting variety of plants and plant communities $(2,3)$.

In late 1994 the Oklahoma Chapter of The Conservancy acquired the site via donation by the landowner. In order to determine whether it was biologically significant and worthy of protection in accordance with its goals, The Conservancy required a floristic survey of the vascular plants present. This survey was to be one part of an overall biological assessment of the property. During the 
1995 and 1996 growing seasons, such a survey was conducted of both the site and the surrounding area of approximately 6.4 hectares. In addition to documenting the plants present, mapping of the site's different communities and physiographic features using Geographic Information Systems (GIS) techniques was completed. The objectives of this work were: 1 ) to compile a list of the vascular plant species present, 2) to document the taxa present via herbarium specimens, 3 ) to compile basic ecological and physiographic data and 4) to produce a site-specific vegetation map using GIS techniques.

\section{SITE DESCRIPTION}

The site of the Conservancy's Pennington Creek Nature Sanctuary and surrounding area is approximately 9.6 hectares, located in central Johnston County, (T3S, R6E, Sec.5, SW 1/4 SW 1/4

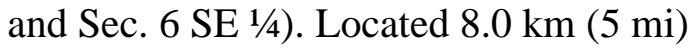
north and $3.2 \mathrm{~km}$ (2 mi) west of Tishomingo, it is bordered by Pennington Creek and a graveled county road on the northeast side. The site is located within the Arbuckle Uplift geomorphic province and the Grand Praire land resources area. The topography consists of gently rolling hills and plains. Ordovician and Cretaceous limestones and Precambrian granites are the parent rock in the area. These granites and rhyolites are the oldest strata in Oklahoma, dating from 1.05 to 1.35 billion years ago, and contribute to this site's uniqueness. They were exposed as sedimentary cover eroded from above them.

Soil types present are the ChigleyGranite outcrop complex with 1 to 8 percent slope and Gracemont soils. The Chigley-Granite outcrop complex consists of a mixture of soils and outcrops of granite. The Chigley soil is a gently sloping, moderately well drained soil on uplands. Its water table is below a depth of $1 \mathrm{~m}$ from February to May and the rate of water intake is moderately slow.

The Gracemont soils are characterized as nearly level to gently sloping, somewhat poorly drained soils in flood plains. Their pattern of soils is intricate; about $35 \%$ of an area has a surface layer of loamy fine sand, and 50\% has a surface layer of fine sandy loam. These soils are next to the stream channels; the water table is below a depth of 0.1-1.0 m (4-40 in) for most of the year; rate of water intake is rapid.

Precipitation for the area of the site averages about $101.8 \mathrm{~cm}$ (40 in) while the average temperature is $16.7^{\circ} \mathrm{C}\left(62^{\circ} \mathrm{F}\right)$. Of the total annual precipitation, 59\% usually falls between the months of April and September. The range of precipitation effectiveness values is from 65 to to 50 . The growing season for Johnston County ranges from 189 to 230 days. The dominant vegetation type for the area is Post Oak-Blackjack Forest.

\section{METHOD OF STUDY}

The major component of this research was the collection and identification of the vascular plants found at the site. During 13 trips from March 1995 to October 1996, vascular plants in fertile condition were collection while the site was systematically traversed on foot. Traditional taxonomic procedures of collecting, pressing, drying, and preservation were employed. Unknown species were identified using the resources of the OSU Herbarium (OKLA). Some plants were identified only to genus because they were not in flower or fruit. Nomenclature was based primarily on that of Waterfall (8) and Gleason and Conquist (9). Common names were taken from Taylor and Taylor (10). Voucher 
specimens were deposited in the OSU Herbarium.

The GIS comprised spatial data layers collected in either digital or analog form from a U.S.G.S. aerial photograph, topographic quadrangle map, and the soil survey map of Johnston County. Elevation and soils coverages were digitized from USGS quad map and the soil survey map of Johnston County, respectively. Coverages of plant communities, road, and creek were derived directly from the digitized aerial photograph. Each spatial data layer was accompanied by a table of attribute or non-spatial data. The plant species coverage included attribute data for a representative group of species from each plant community. Each record in the table comprised scientific name, common name, plant community, habit, collection date, collection number and relative abundance. Spatial relationships between distribution of plant species and parameters of plant communities were compared.

\section{COLLECTION OF SPECIMENS}

Field notes were compiled as each plant was collected and included: a description of the plant's habitat, morphology, topography, associated species; the date; collection number, and any additional comments. These notes were made with a microcassette recorder and later transcribed onto individual data collection sheets for each specimen. A small site map in the lower-right corner of each sheet allowed the general position of each plant collected to be recorded.

Specimens were pressed and dried at approximately $43^{\circ} \mathrm{C}$ for $2-3$ days. The specimens were then placed in a freezer at $0^{\circ} \mathrm{C}$ for a minimum of 1 week. Freezing ensured that all insects and other potential pests were dead before being placed in the herbarium.
Most specimens were identified using Key of the Vascular Plant Families of Oklahoma (17) along with U.T. Waterfall's Keys to the Flora of Oklahoma (8). Keys in the Flora of the Great Plains, Correll and Johnston's Flora of Texas, Gray's Manual of Botany, and Hampton's treatment of the Amaranthaceae (21) were also used to identify plant specimens and herbarium sheets from the OSU herbarium were used to verify identifications. Nomenclature was based primarily on that of Waterfall (8) and Gleason and Cronquist (9).

After the specimens were identified, pressed, and dried they were mounted on herbarium paper. Labels on each specimen provide the scientific name, common name, topography, associated species, collection number, date collected, and relative location of the plant. Each specimen was glued to acid-free herbarium paper with Elmer's Wood Glue ${ }^{\circledR}$, allowed to dry and then refrozen to kill insects before being accessioned to the OSU herbarium.

\section{GIS DATA}

Multiple layers of data were used for this project which was created using the Arcview 3.0 ${ }^{\circledR}$ program developed by the Environmental Systems Research Institute (ESRI). The first steps of the project included scanning, registering, and referencing a U.S.G.S. aerial photograph of the preserve. This data layer was assigned real-world coordinates using U.T.M. coordinates. Four derived coverages including property boundaries, road, creek, and plant communities were created on-screen from the digitized aerial photo. The road, creek, and plant community themes were created as polygon coverages and the property boundary, elevation, and soils themes are line coverages. The elevation and soils 
coverages were digitized directly from a U.S.G.S. quad map (Reagan series) and the Johnston County Soil Survey, respectively. The plant species coverage was added as points within the boundaries of the plant community coverages.

Most of the attribute data came from the derived coverage plant communities. The soil attribute data supplied important information for each plant community. Along with actual soil types, information regarding their depths and drainage properties was included. The point attribute data of the plant species coverage were added from data collected during the 1995-1996 field research seasons.

Analysis of the data represented within each coverage was done as a pointin-polygon analysis. To gain an understanding of the relationships between each species's distribution and the physical features of the site, the plant community layers and the soils layer were linked to each taxon.

Ten coverages were generated in the GIS study: they were study area, species, elevation, soils, penncreek, riparian community, granite community, grassland community, forest community, and road. For each coverage two files, shape and text, were created. The shape file depicts coverages as either polygon, line, or point. The text files describe the shape files by means of tabular attribute or aspatial data. For each coverage, an attribute table comprising three to seven fields and one to 100 records was created. The attribute data below allows coverages to be linked or joined via matching fields.

Study Area:

\section{GIS ATTRIBUTE TABLES}

Shape ID\# Boundary Line

Line 1 Study Area Boundary

Elevation:

Shape ID\# Elevation Line

line $1 \quad 820$ feet

line 2830 feet

line 3840 feet

line $\quad 4 \quad 850$ feet

Soils:

Shape ID\# $\quad$ Soil Type $\quad$ Soil Name $\quad$ Depth High Water Table Depth

$\begin{array}{lllcll}\text { line } & 1 & 6 & \text { Chigley Granite Outcrop } & 0-72 \text { in. } & 3.0-4.0 \mathrm{ft} . \\ \text { line } & 2 & 27 & \text { Gracemont } & 0-74 \mathrm{in.} & 0.5-3.0 \mathrm{ft} .\end{array}$

Riparian Community

\begin{tabular}{llll} 
Shape & ID\# & \multicolumn{2}{l}{ Community } \\
\hline polygon & 1 & RP & Riparian \\
polygon & 2 & RP & Riparian
\end{tabular}

Forest Community

Shape ID\# Community

$\begin{array}{llll}\text { polygon } & 1 & \text { FO } & \text { Forest }\end{array}$ 


\begin{tabular}{lccc} 
polygon & 2 & FO & Forest \\
Grassland Community & & \\
Shape & ID\# & Community \\
\hline polygon & 1 & GR & Grassland \\
polygon & 2 & GR & Grassland
\end{tabular}

Granite Community

\begin{tabular}{|c|c|c|}
\hline Shape & ID\# & Community \\
\hline polygon & 1 & GO Granite outcrop-boulder \\
\hline polygon & 2 & Granite outcrop-ground level \\
\hline \multicolumn{3}{|l|}{ Road: } \\
\hline Shape & ID\# & Road Type \\
\hline polygon & 1 & County Road \\
\hline
\end{tabular}

\section{RESULTS AND DISCUSSION}

Two hundred-three species in 157 genera and 64 families were encountered in this survey (Appendices C-E). The four largest families were the Asteraceae, Poaceae, Fabaceae, and the Cyperaceae (Table 1).These taxa were representative of riparian habitats, post oak-blackjack woods, and prairies.

Table: Number of Genera and Species for the largest Families Present at The Nature Conserancy's Pennington Creek Site.

\begin{tabular}{lll} 
Family & Genera & Species \\
\hline Asteraceae & 24 & 32 \\
Poaceae & 21 & 28 \\
Fabaceae & 11 & 14 \\
Cyperaceae & 4 & 10
\end{tabular}

Species designated by the U.S. Fish and Wildlife Service (11) as endangered, threatened, or Category 1 were not encountered. Although cited as present in the county, Carex fissa (S2imperiled in the state) and Penstemon oklahomensis (S3-very rare in the state) were not discovered. The only species presently ranked by the Oklahoma Natural Heritage Inventory (12) as S1, critically imperiled in the state or S2 was Alnus maritima. A species of interest because of its unusual distribution is Alnus maritima, seaside alder. It is found only in Johnston and Pontotoc Counties along the Blue River, its tributaries, and Pennington Creek (13). This shrub or small tree comprises large populations on the Delmarva Peninsula of southern Delaware and eastern Maryland. The seaside alder's presence in south-central Oklahoma is unexplained. Documentation of the species' existence in the area dates from 1872 (14). Another riparian plant of interest is Lobelia cardinalis. It is an example of a taxon encountered less frequently in its natural setting due to extensive collecting by plant collectors and gardeners.

Present at the preserve are four distinct plant communities: forest, grassland, granitic outcrop, and riparian. The forest community is the largest. It is composed of characteristic crosstimbers taxa. The trees are oak-hickory dominants (15) and include: Quercus stellata, Q. marilandica, Carya texana, $C$. cordiformis, C. illinoensis, Ulmus alata, and U. rubra. Dominant shrubby taxa include Symphoricarpos orbiculatus and 
Rhus copallina. Common herbaceous species present include Elymus canadensis, Geum canadense, Antennaria plantaginifolia, and Carex caroliniana.

Small grassland communities are present in openings of the forest community and consist of a mixture of grasses and forbs. Typical species include Tridens flavus, Gaillardia pulchella, Sorghastrum nutans, Coreopsis tinctoria, Castilleja indivisa, Setaria lutescens, and Bouteloua curtipendula. The granitic outcrop community is the most unique community of the site. It occurs on the shallow, loose soils surrounding the ground-level granite domes. These shallow soils support species such as Sedum pulchellum, S. nuttallianum, Chaetopappa asteroides and Krigia virginica. Many of these species are typical of early successional stages in granite outcrop communities (16). There are also large granite boulders throughout the site, some of which provide habitat on their surfaces or in crevices for taxa such as Polypodium polypodioides, Eragrostis capillaris, and Woodsia obtusa.

The riparian community is characterized by herbaceous species such as Chasmanthium latifolium, Justicia americana, Equisetum hyemale, Ranunculus hispidus, and Lobelia cardinalis. Woody species present include Platanus occidentalis and Alnus maritima. Aquatic macrophytes were not observed in the creek.

The GIS permitted comparison of plant distribution and community parameters by creating multiple layers of spatial data and accompanying attribute data. For example, the distribution of Sedum nuttallianum and S. pulchellum correlated with the occurrence of the Precambrian granite outcrops and the distribution of Lobelia cardinalis with the occurrence of riparian habitat.

\section{ADDENDUM}

\section{Isoetes butleri September 14, 1997}

On two separate dates (May 15 and 31, 1997, Isoetes butleri, Butler's Quillwort, was found on the Nature Conservancy's property at Pennington Creek. This is an important plant species due to its S1 ranking by the Oklahoma Natural Heritage Program. This ranking states that this particular species is critically imperiled in Oklahoma because of extreme rarity (five or fewer occurrences or very few remaining individuals or acres) or because of some factor of its biology making it especially vulnerable to extinction (12).

This perennial aquatic or amphibious plant is found usually from March to June and is most often associated with limestone or calcareous soils (18) but seems to be at home among the granitic outcrops characteristic of central Johnston County. This species was not found or documented before May 1997 due to the extremely dry conditions during the 1996 collecting season. Steady amounts of precipitation during the spring of 1997 helped create conditions required by Isoetes butleri. The presence of Isoetes butleri warrants some degree of protection for this site.

Author's Note:

This site is no longer owned by The Nature Conservency.

\section{LITERATURE CITED}

1. Johnson, K.S. 1971. Guidebook for geologic field trips in Oklahoma. Book I. (preliminary version) [Published by the author]. 
2. Houle, G. 1990. Species-area relationships during primary succession in granite outcrop plant communities. Am. J. Bot. 77:1433-1439.

3. Eddy, A. 1990. Vegetation of ten-acre rock. Proc. Okla. Jr. Acad Sci. 17:4-10.

4. Johnson, K.S. M.R. Burchfield, and W. Harrison. 1984. Guidebook for Arbuckle Mountains field trip, Southern Oklahoma. Norman, OK: University of Oklahoma Press.

5. Oklahoma State Map. 1992. Major land resources areas. Natural Resources Conservation Services. United States Department of Agriculture.

6. Burgess, D.L. 1977. Soil survey of Johnston County, Oklahoma. Soil Conservation Service. U.S. Department of Agriculture

7. Duck, L.G., and J.B. Fletcher. 1943. Game type map of Oklahoma. Division of Wildlife Restoration, Oklahoma Game and Fish Department: Oklahoma City, Oklahoma.

8. Waterfall, U.T. 1969. Keys to the flora of Oklahoma, $4^{\text {th }}$ ed. Stillwater, OK: [Published by the author].

9. Gleason, H.A. and A. Cronquist. 1963. Manual of vascular plants of northeastern United States and adjacent Canada. Prinston, NJ: D. Van Nostrand Company, Inc.

10. Taylor, R.J. and C.E.S. Taylor. An annotated list of the ferns, fern allies, gymnosperms, and flowering plants of Oklahoma, $3^{\text {rd }}$ ed. [Published by the authors at Southeastern Oklahoma State University].

11. U.S. Fish and Wildlife Service. October 31, 1996. Endangered and
Threatened Wildlife and Plants. 50 CFR 17.11-17.12 Washington D.C.

12. Oklahoma Natural Heritage Inventory. 22 January 1997. Short working list of rare plants. Norman, OK: Oklahoma Biological Survey.

13. Zanoni, T.A., J.L. Gentry, R.J. Tyrl, P.G. Risser. 1979. Endangered and threatened plants of Oklahoma. Stillwater, OK: Oklahoma State University, Department of Botany and Microbiology.

14. Sargent, C.S. 1980. The silva of North America. Cambridge, MA: Murray Printing Company.

15. Vankat, J.L., 1992. The natural vegetation of North America, an introduction. Malabar, FL: Krieger Publishing Company.

16. Uno, G.E. and S.L. Collins. 1987. Primary succession on granite outcrops in Southwestern Oklahoma. Bulletin of the Torrey Botanical Club 114(4) 387-392.

17. Tyrl, R.J., Susan Barber, Paul Buck, Wayne Elisens, James Estes, Patricia Folley, Lawrence Magrath, Constance Taylor, and Rahmona Thompson. The flora of Oklahoma. The Flora of Oklahoma Editorial Board. Forthcoming.

18. Great Plains Flora Association. 1986. Flora of the Great Plains. Lawrence, KS: University of Kansas Press.

19. Correll, D.S., and M.C. Johnston. 1979. Manual of the vascular plants of Texas, 2nd printing with revisions. Richardson, TX: University of Texas at Dallas.

20. Fernald, M.L. 1950. Gray’s Manual of Botany. $8^{\text {th }}$ ed. New York, NY: American Book Company.

21. Hampton, R.R. 1996. A taxonomic treatment of the genera and species of the 
Amaranthaceae in Oklahoma [MS thesis]. $\quad$ University. 114 p.

Stillwater, OK: Oklahoma State

\section{Flora of Pennington Creek Preserve}

FAMILY SPECIES COMMON NAME

Acanthaceae Juss.

Acanthus family

Justicia Americana (L.) Vahl

Ruellia Strepens L.

Amaranthaceae Juss.

Amaranthus rudis Sauer

Anacardiaceae Lindl.

Pigweed family

Rhus copallina L.

Cashew family

Toxicodendron radicans Poison Ivy

Apiaceae Lindl.

Chaerophyllum procumbens L.

C. tainturieri Hook.

Cicuta maculata L.

Limnosciadium pinnatum (DC.) Math. \& Const.

Ptilimnium nuttallii (DC.) Britt.

Sanicula canadensis L.

Zizia aurea (L.) Koch

Apocynaceae Juss.

Dogbane family

Amsonia ciliata Walt.

Aquifoliaceae Bartl.

Holly family

Ilex decidua Walt.

Aristolochiaceae Juss.

Birthwort family

Aristolochia tomentosa Sims

Asclepiadaceae R. Br.

Milkweed family

Asclepias asperula(Dcne.) Woods

A. viridis Walt.

Matelea sp.

Aspleniaceae Mett. Ex A.B. Frank

Spleenwort family

Asteraceae Dum.

Asplenium platyneuron (L.) D.C. Eat.
Sunflower family

Achillea millefolium L.

Actinomeris alternifolia (L.) DC.

Antennaria plantaginifolia (L.) DC.

Aster azureus Lindl.

A. sagittifolius Willd.

Bidens polylepis Blake

Chaetopappa asteroides DC.

Chrysopsis pilosa Nutt.

Coreopsis tinctoria Forma tinctoria Nutt.

Elephantopus carolinianus Raeusch. 
Erigeron philadelphicus L.

E. pulchellus Michx.

Eupatorium incarnatum Walt.

E. rugosum Houtt.

E. serotinum Michx.

Gaillardia pulchella Foug.

Gnaphalium purpureum L.

Helenium amarum var. amarum (Raf.) Rock

Helianthus laetiflorus Pers.

Hymenopappus tenuifolius Pursh.

Krigia oppositifolia Raf.

K. virginica (L.) Willd.

Lactuca canadensis L.

Pyrrhopappus carolinianus (Walt.) DC.

P. scaposus DC.

Rudbeckia hirta L.

R. subtomentosa Pursh.

R. triloba L.

Senecio aureus L.

Solidago delicatula Small

Verbesina virginica L.

Vernonia baldwinii Torr.

Betulaceae S.F. Gray

Birch family

Almus maritima Muhl. Ex Nutt.

Brassicaceae Burnett

Mustard family

Cardamine parviflora var. arenicola (Britt). O.E. Schul

C. pensylvanica Muhl.

Lepidium virginicum L.

Cactaceae Juss.

Cactus family

Opuntia macrorhiza Engelm.

Campanulaceae Juss.

Lobelia appendiculata DC.

L. cardinalis L.

Specularia leptocarpa (Nuttali) Gray

S. perfoliata (L.) A. DC.

Caprifoliaceae Juss.

Honeysuckle family

Symphoricarpos orbiculatus Moench.

Viburnum prunifolium L.

Caryophyllaceae Juss.

Pink family

Arenaria serpyllifolia L.

Stellaria media L.

Clusiaceae Lindl.

St. John's-wort family

Hypericum drummondii (Grev. \& Hook) T \& G

$H$. punctatum Lam.

Commelinaceae R. Br.

Spiderwort family

Commelina communis L. 
Cornaceae Dum.

\section{Dogwood family}

Cornus drummondii Meyer

Crassulaceae DC.

Stonecrop family

Sedum nutallianum Raf.

S. pulchellum Michx.

Cucurbitaceae Juss.

Cucumber family

Melothria pendula L.

Cupressaceae Rich. Ex Bartl.

Juniperus virginiana L.

Cyperaceae Juss.

Sedge family

Carex blanda Dewey

C. caroliniana Schwein

C. microdonta Torr. \& Hook

C. planostachys Mack.

C. shortiana Dew.

C. stricta Lam.

Cyperus ovularis (Michx.) Torr.

C. strigosus L.

Eleocharis sp.

Scirpus sp.

Dryopteridaceae Ching Woodfern family

Woodsia obtusa (Spreng.) Torr.

Equisitaceae Rich.

Horsetail family

Equisetum hyemale L.

Euphorbiaceae Juss.

Croton lindheimerianus Scheele.

Euphorbia dentata Michx.

E. maculata L.

E. nutans Lag.

Tragia ramosa Torr.

Fabaceae Lindl.

Bean family

Amorpha fruticosa L.

Baptisia leucophaea Nutt.

Cassia fasiculata Michx.

Cercis canadensis L.

Desmodium canescens (L.) DC.

D. glutinosum (Muhl. Ex Willd.) Wood

D. nudiflorum (L.) DC.

Lespedeza cuneata (Dumont) G. Don

L. virginica (L.) Britt.

Neptunea lutea (Leavenw.) Benth.

Psoralea tenuiflora Pursh

Strophostyles helvola (L.) Ell.

Trifolium dubium Sibth.

Vicia villosa Roth.

Fagaceae Dum.

Oak family

Shannon, K. A. 
Quercus macrocarpa Michx.

Q. marilandica Muench.

Q. muehlenbergii Engelm.

Q. shumardii Buckl.

Q. stellata Wang.

Fumariaceae DC.

Fumitory family

Corydalis micrantha (Engelm.) Gray

Gentianaceae Juss.

Gentian family

Sabatia campestris Nutt.

Hydrophyllaceae R. Br.

Phacelia strictiflora (Engelm. \& Gray) Gray

Iridaceae Juss.

Sisyrinchium angustifolium P. Mill.

Juglandaceae A. Rich. Ex Kunth. Walnut family

Carya cordiformis (Wang.) K. Koch

C. illinoensis (Wang.) K. Koch

C. texana Buckl.

Juglans nigra L.

Juncaceae Juss.

Rush family

Juncus marginatus Rostk.

Juncus sp.

Lamiaceae Lindl.

Mint family

Hedeoma hispida Pursh.

Monarda fistulosa L.

Prunella vulgaris L.

Satureja arkansana (Nutt) Briq.

Scutellaria parvula Michx.

Lilaceae Juss.

Allium canadense L.

Lily family

Hypoxis hirsuta (L.) Coville

Nothoscordum bivalve (L.) Britton

Polygonatum canaliculatum (Muhl.) Pursh.

Lythraceae J. St.-Hil.

Loosestrife family

Lythrum alatum Pursh

Malvaceae Juss.

Mallow family

Callirhoe involucrata (T. \& G.) A.

Menispermaceae Juss.

Moonseed family

Cocculus carolinus (L.) DC.

Moraceae Link

Mulberry family

Maclura pomifera (Raf.) Schneid.

Morus rubra L.

Nyctaginaceae Juss. Four O'clock Family

Mirabilis linearis (Pursh.) Heimerl.

Oleaceae Hoffmsg. \& Link Olive family

Fraxinus americana L.

Onagraceae Juss.

Evening Primrose family

Shannon, K. A. 
Gaura biennis L. var. pitcheri Pickering Ludwigia alternifolia L.

Oenothera linifolia Nutt.

Oxalidaceae R. Br.

Wood Sorrel family

Oxalis corniculata L.

Plantaginaceae Juss.

Plantain family

Plantago purshii R. \& S.

$P$. virginica $\mathrm{L}$.

P. wrightiana Dcne.

Plantanaeae Dum.

Sycamore family

Platanus occidentalis L.

Poaceae Barnh.

Grass family

Agrostis scabra Willd.

Aira elegans Willd. Ex Gaudin

Bothriochloa saccharoides (Sw.) Rydb.

Bouteloua curtipendula (Michs.) Torr.

Bromus japonicus Thunb. Ex Murr.

B. pubescens Muhl. Ex Willd.

B. purgans L.

Chasmanthium latifolium (Michx.) Yates

Cinna arundinacea L.

Echinochloa crus-galli (L.) Beauv.

Elymus virginicus L.

Eragrostis capillaris (L.) Nees

E. spectabilis (Pursh.) Steud.

Festuca arundinacea Schreb.

Lolium multiflorum Lam.

Muhlenbergia sobolifera (Muhl.) Trin.

Panicum acuminatum Swartz.

P. anceps Michx.

$P$. clandestinus L.

P. laxiflorum Lam.

Paspalum dilatatum Poir.

Setaria lutescens (Weigel) Hubb.

Sorghastrum nutans (L.) Nash

Sorghum halepense (L.) Pers.

Sphenopholis obtusata (Michx.) Scribn.

Sporobolus clandestinus (Biehler) Hitchc.

Tridens flavus (L.) Hitchc.

Polemoniaceae Juss.

Polemonium family

Gilia rubra (L.) Wherry

Polygonaceae Juss.

Buckwheat family

Polygonum punctatum Ell.

Rumex hastatulus Baldw.

Polypodiaceae S. F. Gray

True Fern family 
Polypodium polypodioides (L.) Watt

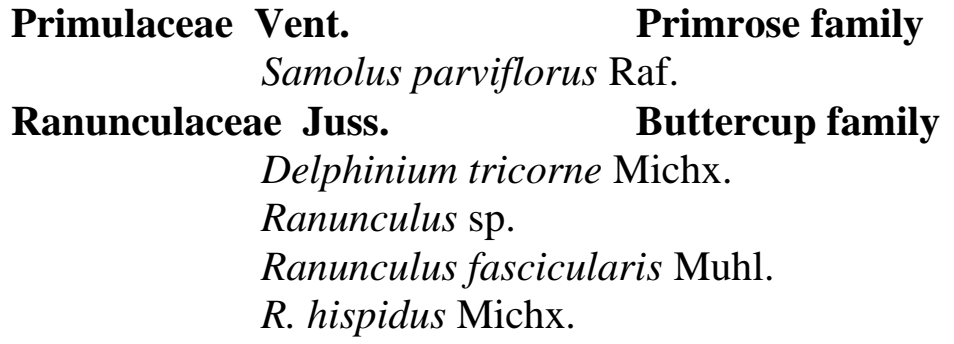
Rhamnaceae Juss. Buckthorn family
Berchemia scandens (Hill) K. Koch
Rhamnus caroliniana Walt.
Rosaceae Juss.
Rose family
Geum canadense Jacq. var. camporum (Rydb.) Fern.
Prunus mexicana S. Wats.
Rosa setigera var. setigera Michx.
Rubus sp.
Rubiaceae Juss.
Madder family
Cephalanthus occidentalis L.
Diodia teres Walt.
Galium aparine L.
G. pilosum Ait.
Hedyotis crassifolia Raf.

Rutaceae Juss.

Citrus family

Zanthoxylum americanum Mill.

Sapotaceae Juss.

Sapodilla family

Bumelia lanuginosa (Michx.) Pers.

Scrophulariaceae

Figwort family

Castilleja indivisa Engelm.

Collinsia violacea Nutt.

Linaria canadensis (L.) Dumont]

Smilaceae Vent.

Greenbrier family

Smilax bona-nox L.

Ulmaceae Mirb.

Elm family

Ulmus alata Michx.

U. rubra Muhl.

Valerianaceae Batsch Valerian family

Valerianella radiata (L.) Dufr.

Verbenaceae St.-Hil. Vervain family

Phryma leptostachya L.

Verbena urticifolia L.

Violaceae Batsch

Violet family

Viola langloisii Greene

$V$. rafinesquii Greene

$V$. sororia Willd.

Vitaceae Juss.

Vitis acerifolia Raf.

Grape family

Shannon, K. A. 